\title{
MEMBACA DASAR-DASAR DAN IMPLEMENTASI FIKIH BUDAYA K.H. MA'RUF AMIN
}

\author{
Abdul Hamid Pujiono ${ }^{\bowtie}$ \\ Sekolah Tinggi Ilmu Fikih (STIF) Syeikh Nawawi Tanara Serang Banten - Indonesia
}

\begin{abstract}
Abstrak
Persepsi budaya tidak bisa dipandang sebagai persepsi artistik. Seringkali masyarakat Indonesia menjadi cerewet, padahal berbicara budaya adalah seni. Padahal cakupan budaya yang luas telah menempatkan seni pada porsi yang masuk di dalamnya. Seni adalah bagian dari budaya. Jadi penerapan dan implementasi budaya pada dasarnya bersifat sehari-hari dan nyata. Tak terpisahkan dan tak terpisahkan dari kehidupan manusia. Oleh karena itu, ekspresi seni untuk merangsang kreativitas dan inovasi tidak dapat disamakan dengan persepsi budaya yang membutuhkan keserasian dan keselarasan. Pemetaan konstelasi fiqih budaya akan mengarah pada realitas sosial politik di Indonesia. Konsep makharij al-fiqhiyyah yang digagas oleh K.H. Ma'ruf Amin akan mengambil jalan tengah. Inilah jawaban atas realitas yang ada, baik yang menyangkut paham, gerakan, politik, maupun ketimpangan sosial. Islam melalui doktrin universal telah memberikan garis-garis budaya, namun pada tataran praksis masih terjebak pada pengaruh masa lalu dan luar.
\end{abstract}

Kata Kunci: fikih budaya, makharij al-fiqhiyyah

\begin{abstract}
Cultural perceptions cannot be viewed as artistic perceptions. Often Indonesian society become talkative, when speaking culture is art. Though wide cultural coverage has placed the art on the portion that goes in it. Art is part of the culture. So the application and implementation of culture is basically daily and real. Integral and inseparable from human life. Therefore, the expression of art to stimulate creativity and innovation can not be equated with cultural perceptions that require harmony and harmony. Mapping the constellation of cultural fiqih will lead to socio-political realities in Indonesia. The concept of makharij al-fiqhiyyah initiated by K.H. Ma'ruf Amin will take the middle course. This is the answers to the existing reality, whether it involves understanding, movement, politics, or social imbalance. Islam through universal doctrine has given cultural outlines, but at the level of praxis still trapped in the past and outside influences.
\end{abstract}

Keywords: culture figh, makharij al-fighiyyah

Copyright (c) 2021 Abdul Hamid Pujiono.

$\triangle$ Corresponding author : Abdul Hamid Pujiono

Email Address : ahimsa900@gmail.com 


\section{PENDAHULUAN}

Secara konseptual, kebudayaan (ats-tsaqafah) diterima sebagai keseluruhan aktivitas kehidupan manusia. Jangkauan dan cakupan yang luas menjadikan budaya sebagai disiplin dan menjadi perhatian khusus di dalam lembaga-lembaga pendidikan dan kementerian Republik Indonesia.

Cakupan budaya tersebut sangat luas. Sebagaimana tergambar dalam beberapa definisi yang diugkapkan oleh para sarjana meliputi: kesenian, moral, adat istiadat, hukum, kepercayaan, dan pengetahuan. Dengan kata lain, gambaran budaya adalah gambaran kehidupan manusia itu sendiri yang didasari dari hasil kreasi pikiran dan perasaan yang bernilai baik.

Budaya yang dimaksud di dalam buku ini adalah yang terdapat di Indonesia. Budaya yang memiliki ciri-ciri dan genealogi tersendiri, meskipun unsur-unsur asing di dalamnya tak dapat diabaikan. Budaya Indonesia yang merepresentasikan warisan budaya Nusantara atau intisari dari kebudayaan Nusantara.

Dari definisi tersebut memunculkan teroi-teori budaya di dalam hukum sebagaimana dikenal kemudian sebagaimana akulturasi dan/atau penerimaan (reseptie). Penolakan Hazairin terhadap teori Snouck Hurgronje (reseptie in contrario) dalam kasus hukum adat menjadi kajian penting, karena di dalam hukum Islam sendiri, adat merupakan instrumen dari penggalian dan penetapan hukum. Pada kasus teori yang dimunculkan oleh Snouck Hurgronje tersebut telah mengakibatkan trikotomi hukum positif di Indonesia menjadi: hukum BW, hukum Islam, dan hukum adat. Sehingga aspek ini menjadi problem besar dalam penerapan bagi pengembangan budaya hukum di Indonesia. Indonesia yang sejati telah menerapkan adat tidak terlepas dari hukum sebagaimana pepatah Minang mengatakan: adat basandi syara', syara' basandi kitabullah. Atau, adat teumeureuhom di Aceh yang menyebutkan: adat bak po teumeureuhom, hokum bak Syiah Kuala, qanun bak Putro Phong, reusam bak laksamana.

Demikian, pikiran dan perasaan yang bernilai baik tersebut memiliki batasanbatasan definisi yang tidak mengikat secara umum. Batasan-batasan definisi tersebut sangat bergantung pada situasi dan kondisi pada ruang dan waktu tertentu. Sehingga sering terjadi tarik menarik antara nilai-nilai umum dan universal terhadap kepentingan dan kebutuhan kondisi psikologis pada lingkungan suatu komunitas masyarakat.

Fikih sebagai buah pikiran sungguh-sungguh (ijtihad) para ulama dalam menghadapi problematika situasional tersebut, mau tidak mau, harus menentukan sikap. Di dalam sejarah hukum Islam (At-Tarikh at-Tasyri'), praktek kodifikasi terjadi setelah mengalami proses yang panjang dalam kurun 300 tahun pasca kenabian. Keterlibatan para ulama dalam menafsirkan ayat-ayat al-Quran, penelitian-penelitian hadis sahih, serta pengambilan hukum (istinbath) telah menempatkan hukum Islam secara istimewa dalam capaian kemajuan peradaban umat Islam. Sehingga kemajuan pesat yang dapat dicatat dengan baik adalah klasifikasi, verifikasi, dan kodifikasi ilmu pengetahuan menjadi beragam disiplin keilmuan. Keterlibatan ulama dalam kontekstasi "teks" turut menentukan kemajuan kebudayaan dalam kekinian (hadlarah). Peradaban yang dipandang sebagai kebudayaan maju akibat dari hasil kreasi pikiran dan perasaan baik umat Islam benar-benar hadir dari dalam prosesnya.

Dengan kata lain, fikih secara mandiri dan budaya sebagai pandangan umum, meskipun pada kasus-kasus tertentu secara tidak harmonis bertentangan dengan 
sufisme ${ }^{1}$, telah saling mengisi dan mampu menghadirkan nalar sehat (common sense) pada suatu lingkungan masyarakat Islam Indonesia. Hal ini dapat dilihat dari ungkapan-ungkapan, peribahasa, aturan-aturan, bahkan norma-norma yang hidup dan disepakati secara turun temurun (at-turats).

Prof. Dr. K..H. Makruf Amin, selanjut ditulis K.H. Ma'ruf Amin, adalah Rais Am, pimpinan tertinggi, Pengurus Besar Nahdlatul Ulama (PBNU) periode 2015-2020 dan Ketua Umum Majelis Ulama Indonesia (MUI) tidak bisa terlepas dari dasar-dasar ungkapan-ungkapan, peribahasa, aturan-aturan, bahkan norma-norma tersebut, ketika menempatkan kaidah-kaidah dasar (ushuli) fikih ke dalam konteksasi dan implementasi hukum di Indonesia.

K.H. Ma'ruf Amin yang berpegang teguh pada kaidah-kaidah dasar fikih mesti bersinggungan erat dengan realitas yang hidup di sekitarnya. Di satu sisi, ia pemegang teguh otoritas prinsip-prinsip keagamaan dalam organisasi resmi PBNU dan MUI, sementara di sisi lain harus menjawab problematika-problematika peradaban yang terus berkembang.

Mekanisme fatwa di dalam menjawab dinamika kehidupan masyarakat Indonesia menjadi piranti penting baginya. Fatwa menjadi alat pemecah kebuntuankebuntuan hukum yang berlaku dengan memberikan respon positif bagi perubahan sosial yang drastis. Meskipun fatwa merupakan instrumen tidak mengikat untuk diikuti. Pada posisi ini, fatwa menjadi himbauan moral yang bersifat tidak mengikat, sekaligus menjadi kerangka acu bagi penegakan moral dalam lingkungan suatu masyarakat di Indonesia. Sebagaimana ulama-kiai yang menjadi rujukan masyarakat dalam mencari jawaban ketika menghadapi problem kehidupan sehari-hari.

Demikian, budaya dalam aspek yang lebih luas telah memberi inspirasi untuk kemajuan peradaban Nusantara, di samping secara khusus hukum menjadi indikator penting dalam penegakannya. Sehingga dasar-dasar dan implementasi yang ditawarkan K.H. Ma'ruf Amin di dalam buku ini menjadi sangat penting.

\section{METODOLOGI}

Tulisan ini menggunakan kajian literature yang sepanjang dapat ditemui dan dimiliki dengan memperhatikan dan mengamati terkait dengan kompetensi yang terdapat dalam ajaran Islam. Asumsi-asumsi yang ditemui dalam kajian tersebut dieksploratif untuk dipahami dan dianalisis dengan membandingkan antara literature satu dengan yang lainnya dengan tujuan untuk mendapatkan gambaran awal yang dapat dijadikan kajian lanjutan secara mendalam dan komprehensif. Secara sederhana metode yang digunakan dalam tulisan ini adalah deskriptif kualitatif.

\section{ANALISIS DAN PEMBAHASAN}

\section{Budaya Dan Problematika Peradaban Nusantara}

\section{A. Islam di Nusantara}

Dalil dan Pengertian budaya diambil secara global dari beberapa definisi berikut:

Dalil Alqur an:

"Jadilah engkau pemaaf dan suruhlah orang mengerjakan yang ma'ruf (tradisi yang baik), serta berpalinglah daripada orang-orang yang bodoh.". (QS. al-A'raf : 199).

Dalil Hadits :

1 Fikih yang bersifat rasional dan menjadi patokan pandangan umum tidak bisa mentolerir keberadaan psikologis sufisme yang cenderung personal dan emosional. Kasus Hamzah Fansuri dan Nuruddin As-Sumatrani adalah yang menonjol di dalam sejarah muslim di Nusantara. 
Abu Hurairah radhiyallahu 'anhu berkata: "Rasulullah shallallahu 'alaihi wasallam bersabda: "Sesungguhnya aku diutus hanyalah untuk menyempurnakan budi pekerti yang mulia." (HR. Ahmad [8939], 2

"Dari Miswar bin Makhramah dan Marwan, Nabi shallallahu 'alaihi wasallam bersabda: "Demi Tuhan yang jiwaku berada pada kekuasaan-Nya, mereka (kaum Musyrik) tidaklah meminta suatu kebiasaan (adat), dimana mereka mengagungkan hak-hak Allah, kecuali aku kabulkan permintaan mereka. ${ }^{3}$," (HR. al-Bukhari [2581])

Islam adalah agama yang diturunkan oleh Allah Ta'ala di bumi gersang Jazirah Arab kepada Rasulul Amin, Muhammad Saw. Di bumi gersang tersebut, Islam tumbuh untuk menata dunia baru dalam situasi yang penuh gejolak. Hal ini ditandai oleh beberapa peristiwa dekadensi moral dan peperangan sejak Islam disiarkan di kota Mekah. Gejolak peristiwa yang terus berlangsung sejak masa Rasulullah Saw hingga terasa saat ini.

Penyebaran Islam di Nusantara dilatarbelakangi oleh beberapa faktor diantaranya: relasi ekonomi dan eksodus.

Relasi ekonomi tumbuh, karena hubungan perdagangan yang telah berlangsung lama. Temuan-temuan arekologis dan nisan bercorak Arab (Arabes), mata uang, dan bangkai-bangkai kapal membuktikan relasi tersebut benar-benar terjadi.

Sementara faktor eksodus ditandai dengan kehadiran Bani Alawiyyin dari Hadramaut yang terus mendapat serangan dari musuh-musuhnya. Mereka melakukan hijrah dan berakulturasi dengan masyarakat di Nusantara. Nusantara merupakan tempat yang subur dan didukung oleh masyarakat yang memiliki pikiran terbuka mampu menerima Islam sebagai agama dan peletak tradisi dan budaya Islam.

Secara teoretik, Islam yang disebarkan di Nusantara mengalami fase yang cukup panjang. Setidak, ada dua teori yang menyebutkan kedatangan kaum muslimin ke Nusantara. Pertama, pelopor dari Gujarat. Dan, kedua, pelopor dari negeri Champa.

Teori pertama menyebutkan Islam masuk melalui pintu pelabuhan Barus di Sumatera Utara dan Aceh sebagai gerbang masuk. Para pedagang dari Timur Tengah, terutama Hadramaut, singgah di Gujarat (India) kemudian menyebar ke seantero Nusantara.

Teori kedua menyebutkan, Islam dibawa oleh para bangsawan kerajaan Champa yang telah luluh lantak diserang oleh kerajaan dari China. Keberadaan kuburan-kuburan puteri Champa yang berdampingan dengan kuburan para bangsawan di Nusantara menjadi identik dengan masuknya Islam.

Peradaban di Nusantara yang telah dibangun sejak ribuan tahun yang lalu telah memberi peluang bagi proses akulturasi budaya terbuka. Di mulai dari relasi perdagangan, tukar menukar cinderamata, bantuan militer, hingga kesenian dan sastra. Langkan-langkan candi yang menyisakan cerita-cerita, wayang-wayang, tembangtembang, pantun-pantun, dan syair-syair telah membuktikan Nusantara memiliki corak dan ciri khas tersendiri. Begitu pula, teknologi-teknologi: pertanian, pengairan, perkapalan, dan arsitektur bangunan telah mencapai peradaban tinggi. Hal ini dapat dimisalkan dengan perbedaan candi-candi di Jawa dan candi-candi yang berada di Thailand atau India. Perbedaan tersebut melahirkan ciri khas dan karakter budaya tersendiri yang dimiliki oleh budaya Nusantara.

Peradaban maritim melalui jalur sungai dan laut telah memberi warna dan corak pada watak manusia Nusantara. Watak yang keras terhadap tantangan alam sekaligus guyub dalam gotong royong. Pendirian lumbung-lumbung padi dan pengasapan ikan membuktikan secara ekonomi ada nilai-nilai kebersamaan masyarakat Nusantara saling bahu membahu dalam menghadapi kesulitan. Nilai-nilai

\footnotetext{
2 Musnad Ahmad, nomer 8595
}

3 Sahih bukari, nomer 2581 
yang bersesuaian dengan nilai-nilai universalitas Islam. Ada keyakinan yang sama dalam membangun tatanan masyarakat.

Penemuan yang membuktikan sistem kepercayaan masyarakat Nusantara terhadap kekuatan Adi kodrati di luar jangkauan nalar manusia, misalnya, tidak berbeda dengan sistem yang dinyatakan di dalam ayat al-Quran sebagai: al-ladzi yukminuna bil ghaib. Nilai-nilai religi yang sama sekali sangat dijunjung tinggi di dalam Islam.

Demikian, Islam masuk ke dalam sistem-sistem yang berlaku di lingkungan masyarakat Nusantara. Sebagaimana sistem hukum, sosial, pemerintahan, dan kepercayaan. Di dalam sistem kepercayaan, Islam memberikan justifikasi relasi melalui "perantara" atau "washilah". Sistem yang sudah menjadi tradisi di Nusantara melalui wewangi dan bebungaan dalam ritual persajian. Simbol-simbol sistem kepercayaan tergambar dalam "pendewaan" yang juga dimanifestasikan sebagai tahapan "seorang guru suci" untuk mendekatkan diri kepadaNya, sebagaimana kisah wayangan Dewa Ruci yang legendaris. Guru-guru tarekat sebagai "orang suci" dapat menggantikan posisi penting "orang suci" yang sebelumnya diperankan oleh dukun-dukun panutan masyarakat.

Di dalam sistem tata pemerintahan, seorang sultan telah menggantikan peran seorang "Raja Dewa", karena disyaratkan harus memiliki kesalehan yang tinggi. Begitu pula, kedudukan para ulama yang menggantikan posisi penting para resi dan brahmana sebagai penasehat raja. Jika di dalam kisah legenda seorang Ken Arok didukung oleh para brahmana ketika melawan Jayakatwang di Kediri, maka Dewan Walisanga telah mengganti posisi itu sebagai penasehat sultan.

Merujuk kepada muktamar NU tahun 1935 di Banjarmasin, K.H. Ma'ruf Amin menegaskan Nusantara sebagai Dar al-sulh, negeri damai. Gejolak peperangan antar suku dan aliran keagamaan di tanah Arab hampir tidak terjadi di Nusantara. Hal ini dapat dibaca di dalam kitab-kitab fikih yang menyebutkan batasan-batasan Dar al-harb (negeri perang) dan Dar al-dzimmi (negeri suaka).

Kemajuan Nusantara dalam mendaur ulang paham-paham keagamaan yang beraliran keras telah berhasil merangkum empat mazhab yang menjadi panutan umat Islam melalui Ahlu al-Sunnah wa al-Jama'ah. Aliran sintesis dari dua aliran radikal sebelum: jabariyah dan qadariyah. Ahlu al-Sunnah wa al-Jama'ah memberi ruang bagi rasionalitas (akal), namun tetap berpegang teguh pada wahyu (Al-Quran dan hadis).

\section{B. Tradisi dan Agama}

Masyarakat Nusantara memiliki tradisi yang kaya. Mulai dari tradisi kelahiran, pengantin, kematian, tolak balak, maupun bersih desa.

Islam tidak mengabaikan kenyataan tradisi dan agama memiliki persenyawaan. Islam yang bersenyawa dengan tradisi menjadi penting dan telah menjadi rutinitas ritual kehidupan masyarakat di Nusantara. Melalui pintu tradisi ini, Islam dapat berkembang dengan diiringi oleh berbagai varian diantaranya kesenian. Justifikasi 'urf atau kaidah al-'adah muhakkamah menempatkan tradisi sebagai ujung tombak strategi kebudayaan. Semisal, persembahan "Raja Dewa" menjadi ritual grebeg besar dan grebeg mulud di kalangan istana kerajaan Demak dan Mataram.

Produk-produk budaya seperti makanan, tata cara ibadah (kaifiyat), teknologi, dan buku.

\section{Indonesia dan Kemodernan}

Bentangan wilayah Nusantara sangat luas. Dari sisi lautan pasifik di timur hingga Madagaskar di barat. Bentangan tersebut sejak kebijakan kolonialisme telah menjadi berbagai negara-bangsa (nation state) dengan wilayah yang lebih sempit. 
Indonesia sebagai negara pewaris terbesar memiliki luasan wilayah yang lebar. Dalam konvensi Jenewa, luasan wilayah suatu negara disebutkan tidak saja meliputi batas tanah, melainkan juga zona kelautan. Dengan kata lain, batas lebar wilayah kelautan sama dengan batas lebar wilayah daratan. Hal ini sangat menguntungkan. Sehingga pola negara modern memerlukan tata pemerintahan tersendiri yang lebih lengkap melalui konsep negara kesatuan. Negara yang semula dikuasai oleh raja-raja tersebut, sejak pasca kolonialisme menjadi negara satu kesatuan.

Dengan keluasan wilayah dan keragaman suku bangsa yang mendiami Indonesia secara tidak langsung memerlukan tatanan yang lebih lengkap dalam pengelolaannya. Menghindari konflik ras, suku, agama, dan antar golongan adalah target utama dengan mengedepankan konsep dan strategi budaya yang matang. Demikian, pengalaman sejarah dan penemuan unsur-unsur universal sangat diperlukan dalam mempertahankan keutuhan Negara Kesatuan Republik Indonesia dengan keragamannya. Sejarah dan penemuan unsur-unsur tersebut yang dapat menentukan relasi agama dan negara.

\section{Ketauhidan dalam Pancasila}

Kontroversi penghapusan tujuh kata dalam Piagam Jakarta masih menyisakan perdebatan hingga kini. Meski secara sah sudah ditetapkan di dalam UUD 1945, namun tuntutan mayoritas umat Islam masih bersemangat untuk menegakkan syariat Islam di Indonesia.

Ketauhidan di dalam Pancasila pada dasarnya sudah diterima oleh semua agama-agama yang ada di Indonesia melalui diskusi dan perdebatan panjang. Karena keesaan merupakan hakikat ajaran semua agama (millata abikum) Ibrahimiah. Hanya pada tataran syariat (jalan dan metode) pencapaiannya yang berbeda. Secara substantif, ada dan tidak adanya tujuh kata yang dihapus dalam Piagam Jakarta tidak menjadi persoalan, karena tujuan-tujuan agama dapat ditampung ke dalam bentuk perundangundangan dan peraturan-peraturan lain yang lebih terperinci.

Secara organisasi, NU sudah menerima Pancasila sebagai dasar bernegara. Hal tersebut ditetapkan pada muktamar NU di Situbondo tahun 1989.

\section{Pandangan K.H. Ma'ruf Amin Tentang Garis-garis Besar Budaya Nusantara}

\section{A. Latar Belakang K.H. Ma'ruf Amin}

Garis-garis besar budaya Nusantara yang dimaksud di dalam buku ini adalah dasar-dasar dan pokok-pokok yang berlandaskan pada norma-norma kebudayaan Nusantara ditinjau dari sudut pandang K.H. Ma'ruf Amin.

K.H. Ma'ruf Amin memiliki jenjang reputasi yang panjang dalam bidang fatwafatwa keagamaan. Posisi-posisi yang diemban dan dilaluinya tersebut senantiasa erat berhubungan dengan birokrasi pemerintahan dan hukum publik sehingga selalu menjadi perhatian besar masyarakat Indonesia, terutama umat Islam. Sebagai ulama sekaligus tokoh yang pernah berkecimpung di ranah politik, fatwa-fatwa yang dikeluarkan olehnya menjadi perhatian serius oleh pemerintah di dalam mengambil kebijakan hukum dan politik yang berkaitan erat dengan hajat umat Islam dan bangsa Indonesia.

K.H. Ma'ruf Amin lahir di Tangerang 11 Maret 1943. Ia memulai pendidikan dasarnya di kampung halaman pada Sekolah Rakyat (SR) tahun 1955. Kemudian, melanjutkan pendidikan di Pondok Pesantren Tebuireng Jombang (1961), serta pesantren-pesantren di Banten (1961-1963). Secara formal, ia menamatkan pendidikan tinggi di Universitas Ibnu Chaldun (1967) dan mendapat anugerah gelar Doktor Honoris Causa dalam bidang hukum Ekonomi dari Universitas Islam Negeri Syarif Hidayatullah Jakarta (2012), dan yang mutakhir adalah Anugerah gelar tertinggi 
akademik diberikan kepada Kiai Ma'ruf Amin sebagai Guru Besar di bidang Mu'amalah Syar'iyah di Fakultas Syariah UIN Maulana Malik Ibrahim, Malang, (2017).

\section{B. Pengalaman Organisasi}

Perjalanan karir organisasi K.H. Ma'ruf Amin bermula dari Ketua Cabang GP Ansor Tanjungpriok (1964-1966), Ketua Front Pemuda (1964-1967), Ketua NU Cabang Tanjungpriok (1968-1976), anggota Pengurus Lembaga Dakwah PBNU Jakarta (1977-1989), Katib Aam Syuriah PBNU (1989-1994), Rais Syuriah PBNU (1994-1998), Mustasyar PBNU 91998-2000), dan Rais PBNU (2004-2015), Rais Aam PBNU (2015-).

Di dunia politik, Ketua Fraksi Golongan Islam DPRD DKI Jakarta (1971-1973), Ketua Fraksi PPP DPRD DKI Jakarta (1973-1977), Pimpinan Komisi A DPRD DKI Jakarta (1977-1982), Anggota MPR RI (1997-1999), Anggota DPR/MPR RI (1999-2004), Ketua Komisi VI DPR RI (1999-2001), Ketua Dewan Syuro DPP PKB (1998-2000), Anggota Dewan Pertimbangan Presiden (2007-2014).

\section{Fatwa dalam Sistem Hukum Islam}

K.H. Ma'ruf Amin tidak bisa terlepas dari gagasan fatwa hukum Islam di Indonesia. Dia termasuk salah satu tokoh terkemuka di Indonesia yang berperan penting dalam kemajuan sistem hukum Islam. Melalui fatwa, dia menempatkan hukum Islam menjadi penentu dalam memberikan solusi kebuntuan ijtihad untuk kasus-kasus kontemporer, sebagaimana ekonomi perbankan.

Pengertian fatwa diambil dari bahasa Arab al-fatwa, bentuk kata dasar yang bermakna muda, baru, penjelasan, dan penerangan. Kata yang berkonotasi pemuda yang kuat. Sehingga, menurut K.H. Ma'ruf Amin, orang yang mengeluarkan fatwa dikatakan sebagai mufti, karena diyakini mempunyai kekuatan dalam memberikan penjelasan dan jawaban yang dihadapinya sebagaimana seorang pemuda. Mengutip dari Zamakhsyari (w $538 \mathrm{H}$ ), fatwa berarti "penjelasan hukum Syara tentang suatu masalah atas pertanyaan seseorang atau kelompok". Sementara As-Syatibi mengajukan definisi sebagai "keterangan-keterangan tentang hukum Syara yang tidak mengikat untuk diikuti".

Dari definisi fatwa tersebut, K.H. MA'ruf Amin menggarisbawahi dua hal: pertama, fatwa bersifat responsif, karena merupakan jawaban hukum (legal opinion) atas pertanyaan atau permintaan fatwa. Fatwa dikeluarkan sebagai jawaban atas pertanyaan yang merupakan peristiwa atau kasus yang telah terjadi atau nyata. Kedua, dari segi kekuatan hukum, fatwa sebagai jawaban hukum tidak bersifat mengikat. ${ }^{4}$

Namun demikian, meskipun fatwa merupakan jawaban responsif dan tidak mengikat untuk diikuti tetap memiliki konsekuensi logis yang harus diperhatikan oleh seorang pemberi fatwa (mufti), sebagaimana kehati-hatian dalam mengeluarkan fatwa dan syarat-syarat yang harus dipenuhi. Sebab, fatwa yang dikeluarkan oleh pihak atau orang yang tidak memenuhi syarat sama saja membuat-buat hukum (tahakkum) yang dilarang oleh agama. ${ }^{5}$

Kehati-hatian dalam berfatwa, menurut K.H. Ma'ruf Amin, telah dicontohkan oleh ulama-ulama terdahulu (salafus shalih) sebagaimana Ibnu Mas'ud r.a., Ibnu Abbas r.a., Imam Malik, Imam Hanafi, Imam Syafii, dan Imam Ahmad bin Hanbal. Mereka tidak gegabah di dalam mengeluarkan fatwa, meskipun telah memenuhi syarat sebagai seorang mufti. Secara spesifik, Imam Ahmad bin Hanbal menyebutkan lima syarat: pertama, mempunyai niat tulus dan ikhlas; kedua, mempunyai ketenangan dan kewibawaan; ketiga, mempunyai kapasitas keilmuan yang memadai; keempat,

\footnotetext{
${ }^{4}$ K.H. Ma'ruf Amin, Fatwa dalam Sistem Hukum Islam (Jakarta: eLSAS, 2017), halaman 20-22.
}

${ }^{5}$ K.H. Ma'ruf Amin, Fatwa dalam..., halaman 30. 
mempunyai kecukupan dalam kehidupan sehingga pendapatnya independen; dan kelima, memiliki kecermatan dan kecerdasan. ${ }^{6}$

Selain syarat-syarat tersebut, model atau bentuk fatwa dapat dibagi menjadi dua macam: pertama, ijtihad fardiy (perorangan) dan, kedua, ijtihad jama'i (kolektif). Di masa sekarang, menurut K.H. Ma'ruf Amin, ijtihad jama'i dipandang lebih utama daripada ijtihad fardiy. Di samping telah mendapat legitimasi dari AlQuran, Sunnah, dan praktek sahabat dan tabiin, fatwa juga perlu mempertimbangkan faktor-faktor perkembangan modernisasi dalam segala segi kehidupan yang kian kompleks dan perkembangan spesialisasi ilmu pengetahuan. ${ }^{7}$ Dengan kata lain, fatwa yang dikeluarkan oleh para ulama juga memerlukan keterangan para ahli (experts) pada disiplin ilmu yang lain, seperti kedokteran dan kriminologi.

Dengan demikian, fatwa menempati posisi penting di dalam sistem hukum Islam, karena kebutuhan akan jawaban-jawaban dari permasalahan-permasalahan yang muncul dan terus berkembang di masyarakat.

Pada posisi ini, peran dan tanggung jawab ulama dituntut untuk tetap menjaga dasar-dasar penerapan (tathbiq) hukum sesuai Syara, di samping terus berdialog dengan perkembangan dan perubahan zaman.

Hadis nabi Muhammad saw menyatakan, "Sesungguhnya ulama adalah pewaris nabi." Nabi tidak meninggalkan warisan, kecuali Al-Quran dan hadis. K.H. Ma'ruf Amin menyatakan, "...sebagai waratsat al-anbiya', ulama mempunyai mas'uliyah (tanggung jawab) dalam membina, membimbing dan mengarahkan umat, baik yang menyangkut keagamaan (diniyah), aspek kemasyarakatan (ijitima'iyah), maupun aspek kebangsaan." 8

Di dalam rumusan tanggung jawab ulama tersebut, K.H. Ma'ruf Amin membagi menjadi tiga: tanggung jawab keagamaan (mas'uliyah diniyyah), tanggung jawab keummatan (mas'uliyah ummatiyah), dan tanggung jawab kebangsaan (mas'uliyah wathaniyyah).

Di dalam tanggung jawab keagamaan, ulama dituntut untuk berdakwah, suatu proses penyampaian, ajakan atau seruan kepada orang lain atau kepada masyarakat untuk memeluk, mempelajari, dan mengamalkan ajaran agama secara sadar. Tugas mengajak ini tidak saja menjadi tanggung jawab ulama, melainkan setiap muslim dan komponen-komponen sosial pada umumnya. Komponen serupa sekelompok orang sebagaimana ditegaskan di dalam ayat Al-Quran:

Waltakum minkum ummatun yad'una ilal khair wa ya'muruna bil ma'ruf wa yanhawna 'anil munkar (Al-Imran, 104). Ulama dalam tugas dan tanggung jawab ini, menurut K.H. Ma'ruf Amin, harus memperhatikan: nilai-nilai masyarakat, seperti kepercayaan, agama, dan tradisi; tingkat pengetahuan masyarakat; tingkat keterampilan masyarakat, dan; bahasa yang digunakan oleh masyarakat.

Kemudian, penerapan syari'ah (tathbiq syari'ah), baik perilaku maupun regulasinya. Ulama dituntut untuk mendorong penerapan syari'ah dalam kehidupan sehari-hari, baik secara langsung maupun melalui undang-undang pada konstitusi negara. Perilaku ulama secara integral harus mampu mencerminkan pengamalan agama, sehingga patut menjadi contoh yang baik (uswatun hasanah) bagi masyarakat.

Berkaitan dengan mas'uliyah ummatiyah, seorang ulama memiliki tanggung jawab memelihara dan membimbing umat (mas'uliyat al-ri'ayah wa al-himayah). Ulama harus mengajak mayoritas umat Islam Indonesia untuk menjadi bagian warga bangsa

\footnotetext{
${ }^{6}$ K.H. Ma'ruf Amin, Fatwa dalam..., halaman 33-34.

${ }^{7}$ K.H. Ma'ruf Amin, Fatwa dalam..., halaman 50.

8 K.H. Ma'ruf Amin, Era Baru Ekonomi Islam Indonesia (Jakarta: eLSAS, 2017), halaman 71.
} 
yang memajukan bangsa dan negara. Di samping, melindungi umat dari ekses-ekses global yang negatif seperti pemikiran yang batil dan gerakan radikalisme.

Sementara mas'uliyah wathaniyah, ulama sebagai bagian dari masyarakat bangsa Indonesia patut memelihara dan menjaga keutuhan Negara Kesatuan Republik Indonesia serta konsensus nasional. Kesepakatan bangsa Indonesia untuk membentuk Negara Kesatuan republik Indonesia dengan Pancasila dan Undangundang Dasar 1945 sebagai falsafah sekaligus konsitusi untuk memelihara keluhuran agama dan mengatur kesejahteraan yang mengikat seluruh elemen bangsa. ${ }^{9}$

Di dalam kerangka berbangsa dan bernegara tersebut, tanggung jawab ulama untuk memberikan sumbangan besar pikiran sungguh-sungguh (ijtihadiyah), di samping sebagai pemelihara dan penajaga, juga memerlukan cakupan pandangan yang lebih luas dan global (syumuliyah).

\section{Proyeksi Fikih Budaya}

Kata "fikih" diambil dari kata al-figh yang berarti pemahaman, sebagaimana firman Allah ta'ala dalam surat Hud ayat 91:

Qaalu ya Syuaibu ma nafqahu...

Mengutip dari Abu Hanifah, K.H. Ma'ruf Amin menjelaskan tentang fiqh. Fiqh adalah pengetahuan jiwa mengenai apa yang dimilikinya dan mengenai apa yang diwajibkan atasnya. Fiqh bagi Abu Hanifah adalah hukum-hukum mengenai keyakinan (i'tiqadiyah) seperti iman, hukum-hukum wijdaniyah (akhlak dan tasawuf), dan hukum-hukum amaliah. Istilah yang digunakan olehnya adalah fighul Akbar. Secara spesifik figh belum merujuk pada terminologi belakangan yang khusus membahas tentang hukum. Imam Al-Syafi'i menedefinisikan figh:

Al-ilmu bil ahkam al-syar'yyah al-'amaliyyah al-muktasabi min adillatiha altafshiliyyah.

Ilmu mengenai hukum-hukum praktis syariat yang dihasilkan dari dalil-dalil yang terperinci. ${ }^{10}$

Proyeksi kebudayaan adalah bagaimana fikih membangun peradaban?

Perubahan sosial: Berubah dan yang tetap

Melalui mekanisme fatwa, banyak perangkat yang akan terlibat di dalamnya. Baik ditinjau dari budaya di dalam hukum, atau sebalik, hukum di dalam budaya. Budaya dan hukum sama-sama menempati porsi yang sama. Sehingga proyeksi fikih budaya dapat terimplementasi dengan baik di dalam kehidupan masyarakat. Dengan kata lain, budaya tidak saja berkaitan dengan hukum Syara an sich, melainkan juga standar dan kerangka acu normatif suatu masyarakat.

Di dalam memproyeksikan fikih budaya tersebut, K.H. Ma'ruf Amin mengajukan dua teori untuk menjawab problem-problem kekinian. Pertama, teori tafriq al-halal min al-haram (memisahkan unsur halal dari unsur haram). Kedua, teori $i$ 'adah alnazhar (Rekonstruksi).

Teori tafriq al-halal min al-haram tersebut perlu dikembangkan, karena dalam kasus lembaga-lembaga ekonomi yang ada, terutama ekonomi Syariah, masih belum terlepas dari unsur ribawi. Minimal, lembaga ekonomi Syariah masih berhubungan dengan lembaga ekonomi konvensional dari aspek permodalan, pengembangan produk, maupun keuntungan. Teori ini bisa diterapkan apabila unsur halal lebih besar atau dominan dari unsur haram. Selagi unsur haram tersebut bida diidentifikasi, maka unsur haram tersebut wajib dibuang. Dengan kata lain, uang pada dasarnya adalah halal zatnya ('ainiyah), tapi karena cara memperolehnya (kasbiyah) melalui cara haram,

\footnotetext{
${ }^{9}$ K.H. Ma'ruf Amin, Era Baru Ekonomi Islam Indonesia..., halaman 72-118.
}

10 Al-Mahalli, Syarh Jam' al-Jawami', juz I, halaman 23. 
maka unsur halal dan haram menjadi tercampur. Sehingga keharaman uang tersebut perlu diidentifikasi dan dikeluarkan sehingga tersisa yang halal.

\section{E. Syekh Nawawi Al-Bantani Par-excellence}

Syekh Nawawi Al-Bantani (1814-1897 Masehi) adalah ulama Nusantara terkemuka di Jazirah Arab. Dia adalah guru ulama-ulama besar yang menghabiskan masa hidupnya di Mekah. KHM Hasyim Asy'ari, K.H. Kholil Bangkalan, KHR Asnawi Kudus, K.H. Ahmad Dahlan, dan K.H. Tubagus Bakri Purwakarta adalah di antara ulama-ulama yang pernah berguru kepadanya.

Karya-karya tulisnya meliputi bidang kajian: fikih, tauhid, tasawuf, hadis, sejarah, dan bahasa.

Silsilah dan garis keturunan K.H. Ma'ruf Amin masih dalam puak besar Maulana Hasanuddin, Sultan Banten. Di dalam puak besar ini, K.H. Ma'ruf Amin dan Syekh Nawawi Al-Bantani lahir sebagai ulama terkemuka. Sebagaimana diketahui, Maulana Hasanuddin adalah putera Syarif Hidayatullah atau dikenal dengan Sunan Gunungjati.

Terlahir dari keluarga taat beragama, Syekh Nawawi Al-Bantani memperoleh ilmu dari ayahnya, Umar bin 'Arabi. Oleh ibunya, Zubaidah, ia diberi pesan," Aku doakan dan kurestui kepergianmu mengaji (menuntut ilmu) dengan satu syarat, jangan pulang sebelum pohon yang sengaja kutanam ini berbuah."11 Motivasi ini menggerakkan hati Syekh Nawawi Al-Bantani giat menimba ilmu. Setelah belajar kepada ayahnya, ia berguru kepada Haji Sahal, seorang alim di Banten. Kemudian, kepada Raden Haji Yusuf di Purwakarta.

Di usia lima belas tahun, Syekh Nawawi Al-Bantani mulai mengembara menuntut ilmu di Mekah. Di kota kelahiran Rasulullah saw tersebut, Syekh Nawawi Al-Bantani berguru kepada Syekh Ahmad Nahrawi, Syekh Ahmad Dimyati, serta Syekh Ahmad Zaini Dahlan. Di Madinah, ia belajar kepada Syekh Muhammad Khatib Al-Hanbali. ${ }^{12}$

Pada tahun 1831, Syekh Nawawi Al-Bantani kembali ke tanah air. Ia mengajar di pesantren peninggalan ayahnya dan menyebarkan pengetahuan ke masyarakat. Kobaran api perjuangan Perang Dipanegara (1825-1830) sampai ke Banten. Syekh Nawawi Al-Bantani pun turut mengobarkan semangat perlawanan, sehingga gerakannya menjadi sorotan serius penjajah Belanda. Setelah tiga tahun, ia kembali lagi ke Mekah dan tak pernah kembali lagi ke tanah air. ${ }^{13}$

Di Mekah, Syekh Nawawi Al-Bantani kembali mendalami keilmuannya. Ia menimba ilmu kepada Syekh Muhammad Khatib Sambas, Syekh Abdul Ghani Bima, Syekh Yusuf Sumulaweni, dan Syekh Abdul Hamid Dagastani. Dari Syekh Muhammad Khatib Sambas, ia menerima sanad kemursyidan tarekat Qadiriyah wa Naqsyabandiyah yang kemudian diturunkan kepada muridnya, Syekh Mahfud AtTarmasy. ${ }^{14}$

Tiga puluh tahun, Syekh Nawawi Al-Bantani mendalami ilmu. Selam itu, ia berguru kepada Syekh Muhammad Khatib Sambas, Syekh Abdul Ghani Bima, Syekh Yusuf Sumulaweni, Syekh Abdul Hamid Dagastani, Syekh Muhammad Khatib Duma Al-Hanbali, Syekh Junaid Al-Batawi, Syekh Ahmad Nahrawi, Syekh Muhammad bin Sulaiman Hasbullah Al-Maliki, Syekh Zainuddin Aceh, Syekh Syihabuddin, Sayyidah Fatimah binti Sayyidi Syekh Abdus Shamad Al-Falimbani, Syekh Yusuf bin Arsyad Al-

11 Rohimudin Nawawi al-Bantani, Syekh Nawawi Al-Bantani: Ulama Indonesia yang Menjadi Imam Besar di Masjidil Haram (Depok: PT Melvana Media Indonesia, 2017), halaman 19.

12 Rohimudin Nawawi al-Bantani, Syekh Nawawi..., halaman 21.

13 Rohimudin Nawawi al-Bantani, Syekh Nawawi..., halaman 21-23.

14 Rohimudin Nawawi al-Bantani, Syekh Nawawi..., halaman 23. 
Banjari, Syekh Abdus Shamad bin Abdurrahman Al-Falimbani, dan Syekh Aqib bin Hasanuddin Al-Falimbani. ${ }^{15}$

Syekh Nawawi Al-Bantani menjadi inspirasi K.H. Ma'ruf Amin.

\section{F. Mekanisme Fatwa}

K.H. Ma'ruf Amin berpendapat: fatwa dapat menjadi solusi alternatif bagi kebuntuan pemikiran Islam. Baginya," Ajaran Islam yang dibawa nabi Muhammad saw bersifat universal, tidak terbatas oleh waktu dan tempat tertentu. Ajaran Islam juga berlaku untuk seluruh manusia, di manapun mereka berada." 16 Sehingga universalitas ajaran Islam membawa konsekuensi untuk menjawab semua persoalan yang muncul dari waktu ke waktu. Ajaran tersebut bersumber dari kitab suci al-Quran, juga respon nabi Muhammad saw ketika menghadapi suatu masalah, baik melalui perkataan, perbuatan, maupun pengakuannya. ${ }^{17}$ Respon nabi Muhammad saw tersebut belakangan dikenal dengan sebutan al-Sunnah. Al-Quran dan al-Sunnah tersebut bersifat tetap (fixed) dan secara kuantitatif tidak bertambah maupun berkurang.

Namun demikian, permasalahan umat terus berkembang, sehingga memerlukan mekanisme tersendiri yang sudah diatur secara lebih terperinci ke dalam epistemologi keilmuan Islam untuk menjawab permasalahan umat tersebut.

Menurut K.H. Ma'ruf Amin, ada tiga alasan epistemologis universalitas ajaran Islam yang selalu relavan digunakan di setiap waktu dan tempat (shalihun li kulli zaman wa makan): pertama, Allah swt mendesain teks normatif keagamaan yang terdapat di dalam al-Quran dan al-Sunnah tidak menjelaskan semua hal dalam bentuk terperinci. Karena, teks normatif keagamaan tersebut bersifat: umum ('amm) dan khusus (khas), global (ijmali) dan terperinci (tafshili), serta pasti (qath'i) dan terbuka secara prinsip (zhanni). Kedua, al-Quran didesain untuk menjawab persoalan-persoalan secara global. Sebab, apabila dijelaskan secara terperinci, maka al-Quran tersebut akan kehilangan relavansi dengan dinamika masyarakat yang terus berkembang. Ketiga, kondisi obyektif permasalahan manusia yang terus berkembang mewajibkan bagi orang yang mampu dan memenuhi syarat untuk melakukan ijtihad (usaha sungguh-sungguh untuk penggalian hukum). ${ }^{18}$

Untuk melakukan ijtihad tersebut diperlukan persyaratan dan kriteria yang ketat. Menurut K.H. Ma'ruf Amin, ijtihad tidak mungkin dilakukan oleh setiap orang. Orang yang tidak mampu melakukan ijtihad wajib mengikuti pendapat orang-orang yang ahli (ulama). Salah satu mekanisme yang telah disiapkan oleh epistemologi hukum Islam adalah bertanya dan memohon penjelasan dari orang yang memiliki kompetensi. Termasuk di dalamnya memohon penjelasan tentang status hukum (fatwa) yang belum ada ketetapan hukumnya. ${ }^{19}$

Demikian, fatwa tidak saja memberikan solusi jawaban suatu permasalahan, melainkan juga sebagai alat (mekanisme) dalam merespon perkembangan permasalahan yang bersifat kekinian atau kontemporer. ${ }^{20}$

Untuk kondisi yang tidak mungkin dilakukan fatwa secara individu, karena memerlukan disiplin keilmuan yang komprehensif, maka harus dilakukan secara kolektif kelembagaan. Fatwa secara kolektif-lembaga ini dapat dijumpai dalam organisasi: Majma' Buhuts al-Islami, Majma' al-Figh al-Islami, Majelis Ulama Indonesia, Nahdlatul Ulama, Muhammadiyah, dan organisasi yang senafas. Kondisi sosio-kultur

\footnotetext{
${ }^{15}$ Rohimudin Nawawi al-Bantani, Syekh Nawawi..., halaman 24.

16 K.H. Ma'ruf Amin, Fatwa dalam ..., halaman 2.

17 K.H. Ma'ruf Amin, Fatwa dalam..., halaman 3.

${ }^{18}$ K.H. Ma'ruf Amin, Fatwa dalam..., halaman 5-8.

${ }^{19}$ K.H. Ma'ruf Amin, Fatwa dalam..., halaman 9.

20 K.H. Ma'ruf Amin, Fatwa dalam..., halaman 9.
} 
juga memengaruhi corak dan bentuk fatwa ini sejak mula, sebagaimana tergambar dari beberapa mazhab yang sudah muncul genealoginya sejak masa Rasulullah saw. ${ }^{21}$

Mekanisme fatwa tersebut dibutuhkan, karena kondisi masyarakat senantiasa mengalami perubahan-perubahan: tatanan sosial, budaya, ekonomi, dan sebagainya. Mengutip dari pendapat ahli linguistik dan semantik, bahasa akan mengalami perubahan setiap sembilan puluh tahun. Hal ini, menurut K.H. Ma'ruf Amin, bersesuaian dengan sabda Nabi saw yang menyebutkan: setiap seratus tahun ada orang yang bertugas memperbaharui pemahaman agama. ${ }^{22}$

Qaala Rasulullah saw: innallaha yub'atsu li hadzihil ummah 'ala ra'si kulli miati sanatin man yujaddidu laha dinuha (H.R. Abu Daud).

Dalam konteks sosial, ajaran syariat yang tertuang di dalam fikih sering terlihat searah dengan kehidupan sehari-hari, padahal tidak demikian. Manusia sebagai makhluk dinamis dituntut untuk berkreasi dan kreatif mengembangkan diri sesuai zaman melalui ijtihad. Sehingga dalam kondisi seperti ini perlu ada skala prioritas. Dengan kata lain, manusia dapat lebih didahulukan daripada hukum. ${ }^{23}$ Kehendak manusia (ijtihad) dapat didahulukan daripada hukum melalui mekanisme: reinterpretasi, kontekstualisasi, dan rasionalisasi. Dengan kata lain, kehendak manusia dapat berkembang dengan skala cakupan yang lebih luas. Dengan catatan, hukumhukum ciptaan manusia (wadl'iyyah) tersebut masih tetap dalam koridor hukum syar'iyyah, seperti keadilan dan kemaslahatan yang bisa berubah dan ditafsir ulang sesuai kebutuhan zaman. ${ }^{24}$

\section{G. Urgensi Fatwa}

Kehendak umat Islam untuk memformalkan hukum Syara terus terjadi, sejak sidang-sidang BPUPKI yang melahirkan UUD 1945 dan Pancasila hingga aspirasi dan inspirasi umat Islam secara nyata di dalam bentuk organisasi masyarakat dan lembagalembaga formal keagamaan. Meskipun kenyataan umat Islam secara substantif telah terpenuhi kecukupan kebutuhan-kebutuhan akan hak dan kewajibannya, namun tuntutan formalisme simbol-simbol keIslaman masih terus mengemuka.

Tanpa disadari dua kutub yang sejati saling melengkapi, justeru memicu polarisasi di ranah praksis. Islam substantif versus Islam formalis. Hal ini tidak dapat dipungkiri dari kenyataan sejarah, sebelum Belanda datang di Nusantara, dan secara global wilayah-wilayah kekuasaan sebelum menjadi negara-bangsa (nation state) telah memiliki tatanan tersendiri yang terus menghantui masyarakat bangsa Indonesia. Kenyataan modernisasi sistem bernegara dan berbangsa yang datang sering dihadapi dengan sentimen emosional. Penolakan sering mengakibatkan isu panas.

Namun demikian, menurut K.H. Ma'ruf Amin, kenyataan yang datang dan kenyataan yang ada (dimiliki) dalam konstruksi budaya harus terus dibangun. Mashlahah.

\section{H. Budaya dalam Tinjauan Ushul Fiqh}

Hukum Syara menjadi sumber pokok pengetahuan di dalam sejarah Islam. Pengetahuan berkembang melalui proses dialektika sosial terhadap teks-teks keagamaan (Al-Quran, hadis, dan ilmu-ilmu turunannya). Setiap persoalan yang timbul di masyarakat menjadi bahasan penting para ulama, sehingga, baik ada dan tidak sumber referensinya, hukum akan mencari jawabannya.

Secara keseluruhan, hukum Syara sudah menyangkut budaya kehidupan manusia. Berbicara budaya, maka tidak terlepas dari hukum Syara, terutama bagi umat

${ }^{21}$ K.H. Ma'ruf Amin, Fatwa dalam..., halaman 10-11.

22 K.H. Ma'ruf Amin, Fatwa dalam..., halaman 13.

${ }^{23}$ K.H. Ma'ruf Amin, Fatwa dalam..., halaman 14.

24 K.H. Ma'ruf Amin, Fatwa dalam..., halaman 14. 
Islam yang menggunakan Al-Quran dan hadis sebagai dalil pokoknya. Namun demikian, perangkat dan mekanisme hukum Syara (al-aliyat al-adillah asy-syar'iyyah) secara spesifik menggunakan 'urf sebagai metode dan sumber hukum, meskipun tidak semua ulama menerimanya.

Demikian, memandang posisi 'urf dalam sistem hukum Islam menjadi perlu, ketika berbicara tentang budaya.

1. 'Urf

K.H. Ma'ruf Amin menyebutkan:'urf memiliki cakupan lebih luas daripada adat. Hal ini diambil dari pendapat para ulama ushul fiqh yang membedakan antara 'adah dan 'urf.

'Adah didefinisikan dengan: al-amru al-mutakarir min ghairi 'alaqati 'aqliyyatin. Sesuatu yang dikerjakan secara berulang-ulang tanpa adanya hubungan rasional.

Menurut K.H. Ma'ruf Amin, adat tersebut apabila suatu perbuatan dilakukan secara berulang-ulang menurut hukum akal, tidak dinamakan adat. Adat bisa diartikan secara luas yang menyangkut permasalahan pribadi, seperti kebiasaan tidur seseorang, makan, dan jenis makanan tertentu. Begitu pula persoalan yang berkaitan dengan permasalahan orang banyak. Permasalahan yang berkaitan dengan pemikiran baik dan buruk. Adat bisa ditimbulkan dari hawa nafsu dan kerusakan akhlak, seperti korupsi dan pornografi. ${ }^{25}$ Termasuk juga, perubahan budaya suatu masyarakat daerah yang disebabkan oleh pengaruh budaya asing.

Sementara "úrf secara etimologi berarti "yang baik". Pengertian 'urf menurut ulama ushul fiqh didefinisikan sebagai:

'adatu jumhur qawmin fi qawlin aw fi'lin. Kebiasaan mayoritas kaum, baik dalam perkataan maupun perbuatan.

Menurut K.H. Ma'ruf Amin, sebagaimana dikutip dari Musthafa Ahmad Zarqa dalam kitab al-Madkhal 'ala al-figh al-'Am, menyebutkan 'úrf adalah bagian dari adat yang bersifat lebih umum. Suatu 'úrf harus berlaku pada kebanyakan orang di daerah tertentu, bukan pada pribadi atau kelompok tertentu. 'Urf muncul bukan dari kebiasaan alami yang berlaku dalam kebanyakan adat, melainkan muncul dari pengalaman dan pemikiran, seperti kebiasaan mayoritas masyarakat suatu daerah dalam menentukan keperluan rumah tangga yang diambil dari mas kawin pemberian sang suami. Begitu pula penetapan ukuran tertentu dalam penjualan makanan. ${ }^{26}$

Dengan demikian, yang dimaksud pembahasan para ulama Ushul Fiqh dalam menetapkan salah satu dalil hukum syara adalah 'urf, bukan adat.

Di sini, para ulama Ushul Fiqh kemudian membagi 'urf menjadi tiga macam: pertama, 'urf dilihat dari segi obyeknya, kedua, 'urf dari segi cakupannya, dan ketiga, 'urf dari segi bahasannya.

a. Dilihat dari obyeknya, 'urf dibagi menjadi dua: al-'urf al-lafzhi (kebiasaan yang menyangkut ucapan) dan al'urf al-'amali (kebiasaan yang berbentuk perbuatan). Kebiasaan masyarakat dalam menggunakan ungkapan tertentu yang menentukan makna ungkapan tersebut, seperti kata "daging". Apabila ada masyarakat yang membeli daging di pasar, maka daging yang dimaksud adalah daging sapi, meskipun kata daging bisa berarti daging secara umum. Namun, kata daging tersebut sudah menjadi kesepakatan umum masyarakat; daging yang dimaksud adalah daging sapi.

25 K.H. Ma'ruf Amin, Fatwa dalam..., halaman 242.

26 K.H. Ma'ruf Amin, Fatwa dalam..., halaman 243. 
Sementara kebiasaan yang berbentuk umum berlaku di masyarakat, seperti kebiasaan hari libur kerja dalam seminggu atau kebiasaan masyarakat memakan nasi dalam keseharian.

b. Dari segi cakupannya, 'urf terbagi dua: al-'urf 'am (kebiasaan yang bersifat umum) dan al-'urf al-khash (kebiasaan yang bersifat khusus). Kebiasaan yang bersifat umum dan berlaku secara luas di masyarakat atau suatu daerah, seperti ketentuan berat barang bawaan ke dalam pesawat adalah $20 \mathrm{~kg}$. Sementara kebiasaan yang berlaku di suatu daerah tertentu atau masyarakat tertentu adalah seperti ketentuan masa garansi pada barang tertentu.

c. Dari segi keabsahannya bila dipandang dari segi Syara terbagi dua: al'urfal-shahih (kebiasaan yang dianggap sah) dan al-'urf al-fasid (kebiasaan yang dianggap rusak). Kebiasaan yang dianggap sah adalah yang berlaku di masyarakat tidak bertentangan dengan nash (al-Quran dan hadis), tidak menghilangkan kemashlahatan dan mendatangkan kemadaratan, seperti hadiah tunangan dari si lelaki kepada perempuan yang dipinang, di luar mas kawin. Sementara kebiasaan yang dianggap rusak adalah yang bertentangan dengan dalil-dalil Syara dan kaidahkaidah dasar yang ada dalam Syara, seperti kebiasaan pedagang dalam menghalalkan riba. ${ }^{27}$

\section{Mashlahah}

Secara etimologi, mashlahah berarti "manfaat". Suatu pekerjaan yang mengandung manfaat. ${ }^{28}$ Secara terminologi, terdapat beberapa definisi mashlahah. K.H. Ma'ruf Amin, mengutip dari Imam al-Ghazali, mengartikan: pada prinsipnya mashlahah adalah "mengambil manfaat dan menolak kemudaratan dalam rangka memelihara tujuan-tujuan Syara". Tujuan Syara demikian harus sejalan dengan Syara, meskipun bertentangan dengan tujuan-tujuan manusia, karena kemashlahatan manusia yang sering didasarkan pada kehendak hawa nafsu tidak selamanya didasarkan kepada kehendak Syara. Demikian, yang dimaksud dengan mashlahah adalah kehendak dan tujuan Syara, bukan kehendak dan tujuan manusia. Sehingga tujuan Syara yang harus dipelihara tersebut ada lima: memelihara agama, jiwa, akal, keturunan, dan harta.

Imam al-Syatibi dalam kaitan ini tidak membedakan antara kemaslahatan dunia maupun kemaslahatan akhirat, apabila kemaslahatan tersebut masih memelihara tujuan-tujuan Syara. Sebagaimana dikutip oleh K.H. Ma'ruf Amin, Imam al-Syatibi menyebutkan kemaslahatan dunia yang dicapai seorang hamba Allah harus bertujuan untuk kemaslahatan di akhirat. ${ }^{29}$

Para ulama Ushul Fiqh menetapkan macam-macam mashlahah dari beberapa aspek sebagaimana berikut:

a. Dilihat dari segi kualitas dan kepentingan kemaslahatannya. Mashlahah ini terbagi tiga macam: mashlahah primer (mashlahah al-dlaruriyah), mashlahah sekunder yang mendukung mashlahah primer (mashlahah alhajjiyah), dan mashlahah tersier/pelengkap (mashlahah al-tahsiniyah).

Mashlahah al-dlaruriyah, kemaslahatan pokokumat manusia di dunia dan akhirat: memelihara agama, memelihara jiwa, memelihara akal, memelihara keturunan, dan memelihara harta. Menurut K.H. Ma'ruf

27 K.H. Ma'ruf Amin, Fatwa dalam..., halaman 243-247.

28 K.H. Ma'ruf Amin, Fatwa dalam..., halaman 173.

29 K.H. Ma'ruf Amin, Fatwa dalam..., halaman 173-174. 
Amin, memeluk suatu agama merupakan fitrah dan naluri insani yang tidak bisa diingkari dan dibutuhkan oleh umat manusia. Demikian, Allah mensyariatkan agama yang wajib dipelihara setiap orang, baik akidah, ibadah, maupun mu'amalah.

Mashlahah al-hajjiyah, kemaslahatan untuk menyempurnakan kemaslahatan primer. Misal, dalam hal beribadah, diberi keringanan bagi para musafir untuk meringkas (meng-qashar) shalat.

Mashlahah al-tahsiniyah, kemaslahatan yang bersifat sebagai pelengkap dari kemaslahatan sebelum. Misal, memakan makanan bergizi, berpakaian yang bagus-bagus, dan melakukan ibadah-ibadah sunnah.

b. Dilihat dari segi kandungan mashlahah, para ulama Ushul Fiqh membaginya menjadi: mashlahah al-'ammah dan mashlahah al-khashah. Kemaslahatan umum (mashlahah al-'ammah) yang menyangkut kepentingan orang banyak. Kepentingan mayoritas masyarakat. Misal, para ulama membolehkan membunuh penyebar bid'ah yang dapat merusak akidah umat. Sementara mashlahah al-khashah adalah kemaslahatan pribadi, seperti kemaslahatan pemutusan hubungan perkawinan seseorang yang dinyatakan hilang (mafqud).

c. Dilihat dari segi mashlahah yang berubah dan tidak. Para ulama Ushul Fiqh membagi dua: mashlahah al-tsabitah dan mashlahah al-mutaghaiyyirah. Kemaslahatan yang tetap tidak berubah (mashlahah al-tsabitah) seperti kewajiban ibadah: shalat, puasa, zakat, dan haji. Sementara kemaslahatan yang berubah (mashlahah al-mutaghayyirah), karena perubahan tempat, waktu, dan subyek hukum. Kemaslahatan yang berkaitan dengan mu'amalah dan adat. Misal, jenis makanan yang berbeda-beda pada suatu daerah dengan daerah lain.

d. Dilihat dari segi keberadaan, mashlahah terbagi kepada: mashlahah almu'tabarah, mashlahah al-mulghah, dan mashlahah al-mursalah.

Mashlahah al-mu'barah (kemaslahatan yang didukung oleh Syara). Mashlahah yang didukung oleh dalil khusus, sehingga menjadi dasar bentuk dan jenis kemaslahatan tersebut. Misal, Sayyidina Umar ibn alKhattab mengqiyaskan dera bagi peminum minuman keras sebanyak 80 kali deraan seperti pada penuduh zina, karena alat deraan 40 kali yang diberlakukan Rasulullah Saw terhadap peminum minuman keras adalah terkadang menggunakan sandal dan adakala menggunakan pelepah korma.

Mashlahah al-mulghah (kemaslahatan yang ditolak oleh Syara). Misal, orang yang melakukan hubungan seksual di siang hari pada bulan Ramadan dikenakan hukuman: memerdekakan budak, puasa dua bulan berturut-turut, atau memberi makan 60 orang miskin. Hukuman tersebut harus diterapkan secara berturut-turut, apabila tidak mampu memerdekakan budak, baru dikenakan puasa bulan berturut-turut.

Sementara mashlahah al-mursalah (kemaslahatan yang tidak didukung dan tidak ditolak oleh dalil-dalil Syara). Mashlahah ini terbagi dua: mashlahah al-gharibah (asing) dan mashlahah al-mursalah 
(kemaslahatan yang tidak didukung oleh dalil-dalil Syara, namun didukung oleh sekumpulan makna nash al-Quran dan hadis). ${ }^{30}$

Dengan Demikian, yang dimaksud dengan budaya dalam tinjauan Ushul Fiqh adalah yang bersifat global sebagaimana 'urf, karena menyangkut kehidupan mayoritas masyarakat. Sehingga cerminan budaya adalah pandangan luhur (ma'ruf) suatu masyarakat secara umum.

\section{KESIMPULAN}

NU menempatkan budaya sebagai strategi dalam menggiring perubahan. Setiap keputusan yang muncul berkembang secara kultural dari masyarakat sebagai akar rumput. Sehingga keterlibatan NU dan grand design-nya untuk kemajuan budaya tidak dapat diragukan lagi, karena fikih sebagai bagian dari sumber hukum (yurisprudensi) menjadi sangat dinamis. Demikian, ketika keputusan NU menerima Pancasila sebagai dasar negara dalam aplikasi dan implikasi lebih luas tidak bisa terlepas dari sejarah dan akar budaya yang telah berkembang di masyarakat Nusantara.

\section{Al-muhafazhah 'ala al-qadim al-shalih wal akhdzu bil jadidil ashlah \\ Al-mashlahatu al-'aamah muqaddamatun 'ala al-mashlahah al-khassah.}

Persepsi kebudayaan tidak bisa dipandang sebagai persepsi berkesenian. Sering masyarakat Indonesia menjadi latah, apabila berbicara budaya yang dimaksud adalah berkesenian. Padahal cakupan budaya yang luas telah menempatkan kesenian pada porsi yang masuk di dalamnya. Kesenian adalah bagian dari kebudayaan. Sehingga aplikasi dan implementasi budaya pada hakikat adalah keseharian dan nyata. Integral dan tak terpisahkan dari kehidupan manusia. Dengan kata lain, ekspresi berkesinian yang menuntut kreativitas dan inovasi tidak bisa disamakan dengan persepsi budaya yang menuntut keharmonisan dan keselarasan.

Pemetaan konstelasi fikih budaya akan mengarah kepada realitas sosialpolitik di Indonesia. Konsep makharijal-fiqhiyyah yang digagas oleh K.H. Ma'ruf Amin akan mengambil jalan tengah. Hal ini merupakan jawaban-jawaban terhadap realitas yang ada, baik melibatkan paham, gerakan, politik, maupun ketimpangan sosial. Islam melalui ajaran yang universal telah memberi garisgaris besar budaya, namun pada tataran praksis masih terjebak pada bayangbayang masa lalu dan ekses-ekses pengaruh luar

Namun demikian, respon NU terhadap perkembangan budaya belum menyeluruh. Hal ini ditandai dengan keputusan-keputusan yang dihasilkan oleh Lembaga Bahtsul Masail atau di bawah naungan Dewan Syuriah NU atau masih berkutat pada persoalan hukum ekonomi, politik, dan lingkungan hidup. Sementara yang berkaitan dengan kegiatan seni dan sastra masih terasa kurang, meskipun secara resmi keputusan Muktamar NU di Boyolali telah menetapkan Lembaga Seni Budaya Muslimin Indonesia (Lesbumi) yang lahir sejak tahun 1956, Karena budaya tidak berdiri sendiri. Terdiri dari beragam unsur. Tapi, budaya memiliki garis-garis besar dalam hukum Syara.

NU menempatkan strategi budayanya dalam menggiring perubahan. Setiap keputusan yang muncul berkembang secara kultural dari masyarakat sebagai akar rumput. Sehingga keterlibatan NU dan grand design-nya untuk kemajuan budaya tidak dapat diragukan lagi.

30 K.H. Ma'ruf Amin, Fatwa dalam..., halaman 175-182. 
Keputusan NU menerima Pancasila sebagai dasar negara dalam aplikasi dan implikasi lebih luas tidak bisa terlepas dari sejarah dan akar budaya yang telah berkembang di masyarakat Nusantara

\section{DAFTAR PUSTAKA}

Al-Quran ,Mushaf, PT. Menara Kudus, (Kudus 2010)

Amin, Ma'ruf, K.H., Fatwa dalam Sistem Hukum Islam (Jakarta: eLSAS, 2017)

Amin, Ma'ruf, K.H., Era Baru Ekonomi Islam Indonesia (Jakarta: eLSAS, 2017)

Bantani, Rohimudin Nawawi al-, Syekh Nawawi Al-Bantani: Ulama Indonesia yang Menjadi

Imam Besar di Masjidil Haram (Depok: PT Melvana Media Indonesia, 2017)

Musnad Ahmad, Beirut Dar al-Fikr (2000)

Shahih Muslim, Beirut Dar al-Fikr (2007) 
Membaca Dasar-dasar dan Implementasi Fikih Budaya K.H. Ma'ruf Amin DOI: https://doi.org/10.55252/annawawi.v1i1.7 